DOI: 10.15356/2071-9388_03v09_2016_06

\author{
Alexander F. Finaev ${ }^{1,2^{*}}$, Liu Shiyin ${ }^{1 *}$, Bao Weijia ${ }^{1}$, Jing Li ${ }^{1}$
}

${ }^{1}$ State Key Laboratory of Cryospheric Science, Cold and Arid Regions Environmental and Engineering Research Institute, Chinese Academy of Sciences

2 Institute of Water Problems, Hydropower and Ecology of Tajikistan AS

* Corresponding authors; e-mail: finaeff@gmail.com, liusy@lzb.ac.cn

\title{
CLIMATE CHANGE AND WATER
}

\section{POTENTIAL OF THE PAMIR MOUNTAINS}

\begin{abstract}
The Pamir region supplies water for most countries of the Central Asia. Discussions and arguments with regard to reduction of water resources related to climate change are popular today among various governmental and international institutions being a great concern for modern society. Probable decrease of the Pamirs runoff will affect downstream countries that can face water deficiency. However, there is no scientific rationale behind such disputes. The Pamir region is a remote, high-mountainous and hard-to-access area with scarce observation network and no reliable data. It is not sufficiently investigated in order to perform any assessment of climate change. This article represents results of study of climate parameters change (such as temperature, precipitation and river discharge) in the Pamirs. The study area covers all countries included in this mountain region (Tajikistan, China, Afghanistan and Kyrgyzstan). Observation records, remote sensing data and GIS modeling were used in the present work. Chronological data series were divided into two equal time intervals and were treated as climatic periods. Further analysis of climate change helped to estimate its influence on change of water potential in the Pamirs. The paper considers issues of liquid and solid precipitation change in the study area.
\end{abstract}

KEY WORDS: Pamirs, water resources, climate change, glaciers, glacial areas, river discharge, mountain precipitation.

\section{INTRODUCTION}

The Pamir Mountains are bordering the north-west of the Tibetan Plateau and stretch through the territories of Tajikistan, Kyrgyzstan, Afghanistan and China. High elevated mountain ranges make a great barrier to air streams coming from the west. This results in intense precipitation in the western part of the whole area and windward slopes of high ranges. The most extensive contemporary glaciers are found in the Central Pamir of Tajikistan and in the Kashgar mountains of China. The Pamirs, being a source of major rivers in Central Asia and China, is divided into two large watersheds - the Amu Darya river in the west and upper reaches of the Tarim river in the east. Global warming of climate undoubtedly impacts the snow cover, glaciers' dynamics and water potential of this area. Change of water resources has direct influences on irrigation sector in Central Asian countries and northwestern China. A comprehensive description of the Pamir glaciers was done by Schetinnikov [1998]; theoretical basis of glacial study for this area was developed by Glazyrin [1991]. Estimation and forecast of glacial changes for that part of the region in case of various scenarios have been done by several scientists [Glazyrin and Finaev, 2003]; the Book of articles"Glacial areas of the Pamir-Alay"[1993]; Finaev [1999]. Such estimations were generally done on the basis of records obtained from some glaciers of Tajikistan before 1980. The recent development of remote sensing and geo-information technologies (GIS) allows estimation of glacial changes on a large scale, for instance the Chinese part of the Eastern 
Pamirs [Liu and others, 2008] or the Western Pamirs in Tajikistan [Finaev, 2013]. A thorough review made by some researches [UngerShayesteh and others, 2013] proved that Central Asia has experienced accelerated warming since the 1970s which resulted in shrinkage of glaciers in the Pamirs and Tieng Shan.

In the paper published by Tandong Yao and other [2012], the authors have shown that glacial areas of the Himalayas were shrinking due to change of atmospheric circulation and precipitation decrease, while in the Pamirs precipitation increase was observed from 2006 to 2010. It should be noted that Yao et al, [2012] studied only Chinese part of the Pamirs (the Kashgar ridge) which included the highest peak of Muztagh Ata. However, the greatest glacial areas here stretch to the west and can be found in the Central Pamirs of Tajikistan.

Modeling of climate change and glacial areas under the ADB project TA-7599 [Climate Resiliency for Natural Resources Investments, 2011] has shown that the Pamir glaciers were tending to reduce. There are many earlier works proving degradation of some glaciers [Schetinnikov, 1998]. The catalogue of the Pamir glaciers located in the USSR was published based on aerial photography performed in 1968 [Catalogue of glaciers of the USSR, 1968]. It described parameters of glaciers for 1955-1960. Information provided in the second catalogue of glaciers included the period through 1980 [Catalogue of Pamir and Hissar-Alay glaciation for 1980, 2011]. These data proved reduction of glaciers compared to the information from the first catalogue. No glacial inventory and assessment were done afterwards in the Pamirs. All mentioned studies include only the Tajik side of the Pamirs, although glacial areas are distributed over the territories of China and Afghanistan as well.

The present paper represents an updated review of climate change in the Pamirs based on meteorological and hydrological records, space images and modeling results with the help of GIS. Analyses of different parameters' change such as air temperature, precipitation, snow cover and snow accumulation thickness (in water equivalent) for glacial areas across the whole Pamirs and particular basins of large rivers have been performed in the present study.

\section{STUDY REGION}

Usually "the Pamirs" describes the mountains located between the Pyanj and the Vakhsh rivers (the conditional boundaries are identified along these two rivers). However, this approach is not correct from the hydrological point of view, because river basins include mountain ranges which are not part of the Pamirs by the above definition. Thus, the study area covers the entire basins of the Vakhsh, the Pyanj and the Tarim rivers (including ranges adjacent to the Pamirs). Therefore, the present study considers the area which is larger than the total area of the Pamirs typically mentioned in the scientific literature.

\section{The topography and river systems}

The study area is located at altitudes from $1100 \mathrm{~m}$ up to above $7700 \mathrm{~m}$ asl. Particular features of the Pamir highland allow dividing the whole territory into two parts - the Eastern and the Western Pamirs.

The land forms of the Western Pamirs vary and can be characterized by separate high ridges (up to $3.0-4.0 \mathrm{~km}$ ) alongside with flat river valleys affected by erosion. The main ridges of the Western Pamirs stretch from the southwest to the northeast, where the highest peak is Somoni (Communism) with an elevation of $7495 \mathrm{~m}$ asl. Catchment areas of the Western Pamirs belong to the Pyanj and Vakhsh river basins.

The Eastern Pamirs is a high mountain plateau located at the elevation of 3.8-4.5 $\mathrm{km}$. Small mountain ridges rise over flat valleys at the height of $0.5-1.5 \mathrm{~km}$, and some ranges reach $6.2-6.9 \mathrm{~km}$. This high elevated region is covered with permafrost due to low temperatures. The Kashgar ridge with the highest peaks of Muztag-Ata (7546 m asl.) and Kongurt (7719 m asl.) is located eastward. In 
the central part of the Eastern Pamirs there is an orographic depression with a closed (drainless) basin of the Karakul lake. This territory is protected by mountains from penetration of damp air masses, thus receiving very small amount of precipitation. High mountain plateaus are characterized by wide and flat river valleys. The catchment areas of the Eastern Pamirs belong to the Pyanj and Tarim river basins (Fig. 1). Altitudes of main river basins are presented in Table 1.

Table 1. Altitudes of river basins (according to ASTER DEM, resolution $0.028 \mathrm{~km}$ )

\begin{tabular}{|l|c|c|c|c|}
\hline Basin & $\begin{array}{c}\text { Max } \\
\text { altitude, } \\
\text { masl }\end{array}$ & $\begin{array}{c}\text { Min } \\
\text { altitude, } \\
\text { masl }\end{array}$ & $\begin{array}{c}\text { Mean } \\
\text { altitude, } \\
\text { masl }\end{array}$ & $\begin{array}{c}\text { Area, } \\
\mathbf{k m}^{2}\end{array}$ \\
\hline Tarim & 7630 & 1231 & 3748 & 44157 \\
\hline $\begin{array}{l}\text { Kara- } \\
\text { kul }\end{array}$ & 6721 & 3859 & 4501 & 4543 \\
\hline Pyanj & 7339 & 1200 & 4163 & 71648 \\
\hline Vakhsh & 7445 & 1144 & 3547 & 29005 \\
\hline Total & & & & 149353 \\
\hline
\end{tabular}

\section{The climate}

The most frequently repeated synoptic processes during the cold part of the year are the southwest anticyclone periphery and intrusion of cyclones from the territories of Iran and Afghanistan. Cyclones are the reason for warm and moist air masses. Back of cyclones in the Pamirs are usually characterized by cold air intrusions from the west and the north resulting in temperature decrease and precipitation increase. Clear anticyclone weather is associated with rapid temperature decrease.

During the warm part of the year, anticyclone is the reason for temperature increase. During this period, air masses usually penetrate from temperate zones of the west and from the north. In mountain areas, such intrusions are accompanied by precipitation and decrease of temperature.

Decrease of temperature in mountains depends on elevation. The high-elevated

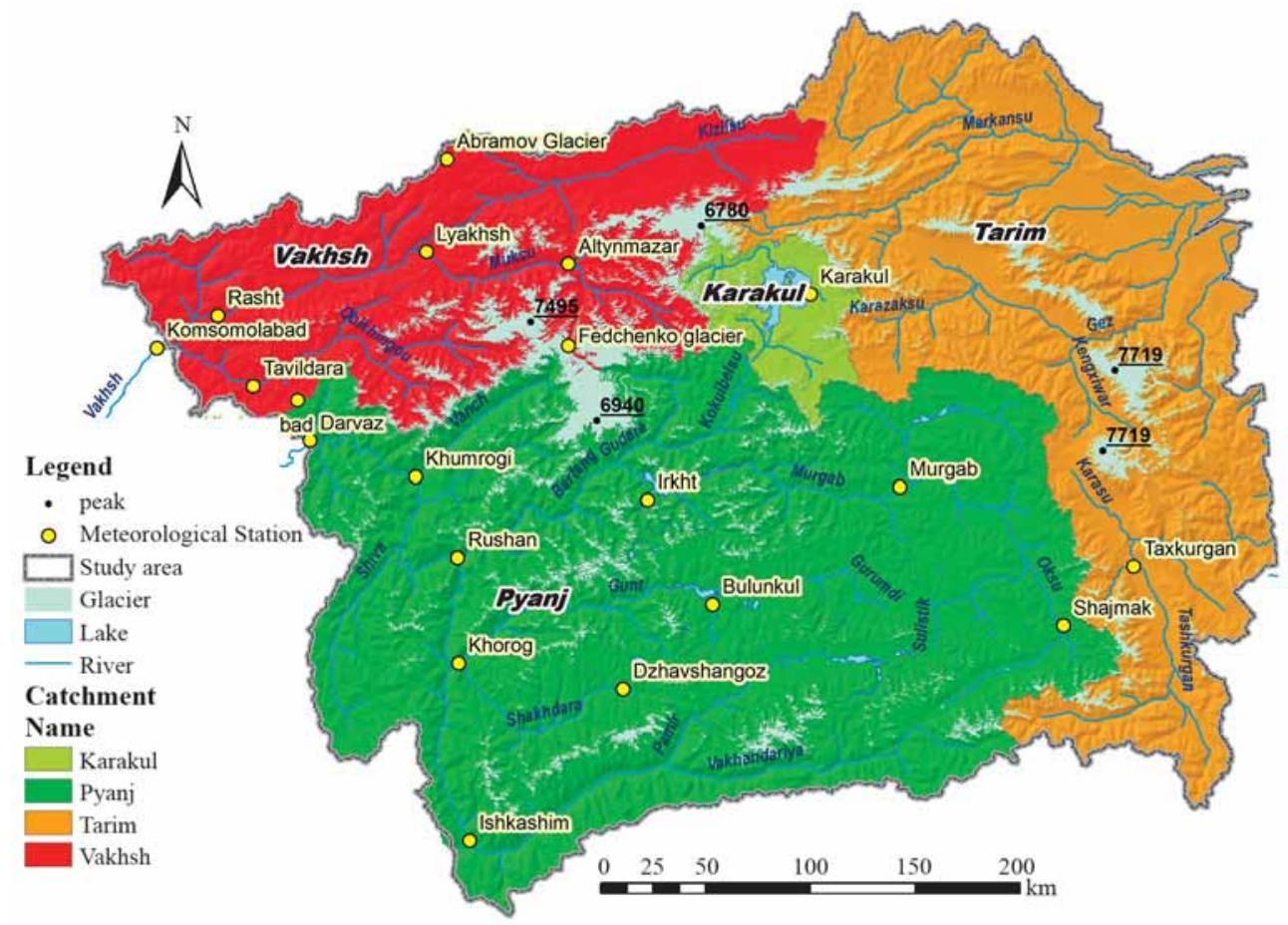

Fig. 1. The main river basins in the study area 
plateaus are very dry. When moving up over windward slopes air masses lose considerable quantity of moisture, and flat land forms do not promote precipitation. Plenty of precipitation usually occurs in upper reaches of valleys open to moisture-containing air streams from the southwest and the south.

\section{Snow cover and glaciers}

Snow cover in the Pamirs can be observed from September to March at the elevation of more than 4-5 km asl. Snow stays all the year round on slopes of northern exposition. The period of the maximum snow cover accumulation throughout the whole area varies from January to May depending on elevation. Melting of steady snow cover could be observed from March to July depending on relief features and surface elevation. The greatest thickness of snow cover varies from $60 \mathrm{~cm}$ at the elevation of $1.0-1.5 \mathrm{~km}$ to 118 $\mathrm{cm}$ at the altitudes higher than $3.5 \mathrm{~km}$.

The highest part of the Pamir mountains contains many glaciers with the total glacial area of more than $10000 \mathrm{~km}^{2}$. The biggest glacial zones can be found in the Central Pamirs (the highest part of the Western Pamirs) and on the Kashgar ridge (KongurMuztag Ata). The largest is the Fedchenko glacier. According to recent studies, its length is $75.4 \mathrm{~km}$ [Finaev, 2013] and its thickness is about 1000 m [Aizen and other, 2009].

\section{DATASETS AND METHODS OF RESEARCH}

\section{Climate data}

Monthly mean air temperature (1927-2008) and monthly precipitation (1927-2009) records from 20 meteorological stations located in the Pamirs were collected for the present study (Figure 1). It is obvious that density of climate stations is low, and they are not evenly distributed over different catchments. For instance, in the Tarim river basin there is only one station, and only one is also in the Karakul lake basin. These two stations are located at altitudes 3930 and 3090 $\mathrm{m}$ asl. In the Vakhsh river basin there are 7 stations ranging from 1258 up to 4169 m asl. In the Pyanj river basin there are 11 stations; the highest one is Shaimak (3840 $\mathrm{m}$ asl.) and the lowest one is Darvaz (1284 m asl).

Station measurements do not hold the common starting time with the earliest in 1927. Besides, gaps can be found in records of some stations. In order to get rid of such discrepancies, all data series have been corrected to match common time interval from 1927 to 2009 using well-known techniques in climatology. Such methodology implies correlation of short-term and longterm station records [Narovlyanskiy, 1968; Pedhazur, 1982; Drozdov and others, 1989; The international meteorological dictionary, $\mathrm{WMO}$, 1992]. In the present study this procedure was done by tools of multiple linear regression available in Microsoft Excel 2010. In order to improve calculation results, 16 stations outside the Pamir territory from Tajikistan, China, Afghanistan, Kyrgyzstan and Pakistan have been included in the study. Totally, records from 36 stations for temperature and records from 35 stations for precipitation have been included.

The term "climate" implies average weather conditions (meteorological parameters) for the period of 30 years and longer. In the present study the total investigated interval is 83 years. In order to estimate probable climate change, the whole time interval has been divided into two climatic periods (CP): from 1927 to 1969, and from 1970 to 2008/2009. Thus, it became possible to analyze real climate change in two climatic periods with the average time interval of 42 and 43 each, instead of estimating trends of meteorological elements, which is usually done based on annual data, and then treated as climate change.

The average altitude of stations is $2740 \mathrm{~m}$ asl, which is $1020 \mathrm{~m}$ lower than the average elevation of the Pamirs according to the Shuttle Radar Terrain Mission (SRTM) digital elevation model (DEM). In conditions of complicated 
mountain relief and big variety of altitudes, records obtained from valley stations cannot correctly illustrate change of climate in high glacial areas. In order to analyze climate change in the Pamirs, it is necessary to have fields of meteorological parameters throughout the investigated territory taking into account surface elevation. Calculations of monthly temperature and precipitation fields for two CP have been done for this purpose.

Despite the fact that all meteorological stations are located in mountain valleys, they are at different altitudes. Since the whole area is not big, change of temperature in case of altitude increase is more significant than its variations related to the stations' locations. Thus, the altitude gradient was used to calculate spatially distributed monthly air temperatures for the Pamir area, which is presented in the formula below:

$T=a \cdot H+b$,

where $a$ and $b$ - coefficients of regression equation for each month in two climatic periods; $\mathrm{H}$ - elevation of the station extracted from the DEM; $T$ - average monthly air temperature. DEM resolution was $0.833 \mathrm{~km}$.

Distribution of precipitation in mountains does not depend on elevation change, but relates more to land forms and air masses movement. Thus, the method used for calculation of temperature is not applicable for precipitation modeling. Information from the World Climate Database (WCD) [Hijmans and other, 2005; www.worldclim. org] was used for calculation of precipitation fields throughout the Pamirs. Time intervals used in the present study (1927-1967 and 1970-2009) and the period represented in the WCD (1950-2000) did not match. This fact causes differences between precipitation grid from the WCD and the average monthly records from the meteorological stations. However, the advantage of the WCD is that it can characterize relative distribution of precipitation over a particular territory taking into account surface elevation and various climate conditions. In order to have reliable precipitation distribution throughout the Pamirs, calibration between data from the WCD and the stations records have been done for each month in both CP. Error $\left(\mathrm{Er}_{\mathrm{st}}\right)$ between precipitation data from WCD $\left(P_{\text {wcd }}\right)$ and records at each station was calculated for this purpose.

$E r_{s t}=P_{w c d}-P_{s t^{\prime}}$

where $\mathrm{Er}_{\text {st }}$ - the WCD error at the station; $\mathrm{P}_{\text {wcd }}$ - precipitation at the station according to WCD; $P_{\text {st }}$ - actual precipitation at the station.

The field of errors $\left(F_{E r}\right)$ for the entire territory has been calculated according to the obtained error results $\mathrm{Er}_{\mathrm{st}}$. Then the WCD field has been calibrated using the error field $\left(F_{E r}\right)$.

$W C D_{\text {crect }}=F_{W C D}+F_{E r}$

where WCD $_{\text {Crrect }}$ - the WCD corrected field; $F_{W C D}$ - the WCD field; $F_{E r}$ - the error filed.

As a result, the corrected precipitation grids for each month in both climatic periods were calculated. Assessment of grids and volume of solid precipitation (snow) has been done for conditions when temperature was below or equal to zero $(T<=0)$.

\section{Hydrological and glaciological data}

Available observation records obtained from hydrological stations of Tajikistan have been used for water discharge analysis (Fig. 2). Using the abovementioned methodology, all observation records have been equalized to one time interval from 1932 to 2009. Records from hydrological stations of other countries were not available.

The Darbant hydrological station is located right on the border of the investigated area, thus it observes water discharge of the Vakhsh river basin which is located in the Pamirs. The Shidz hydrological station represents only 


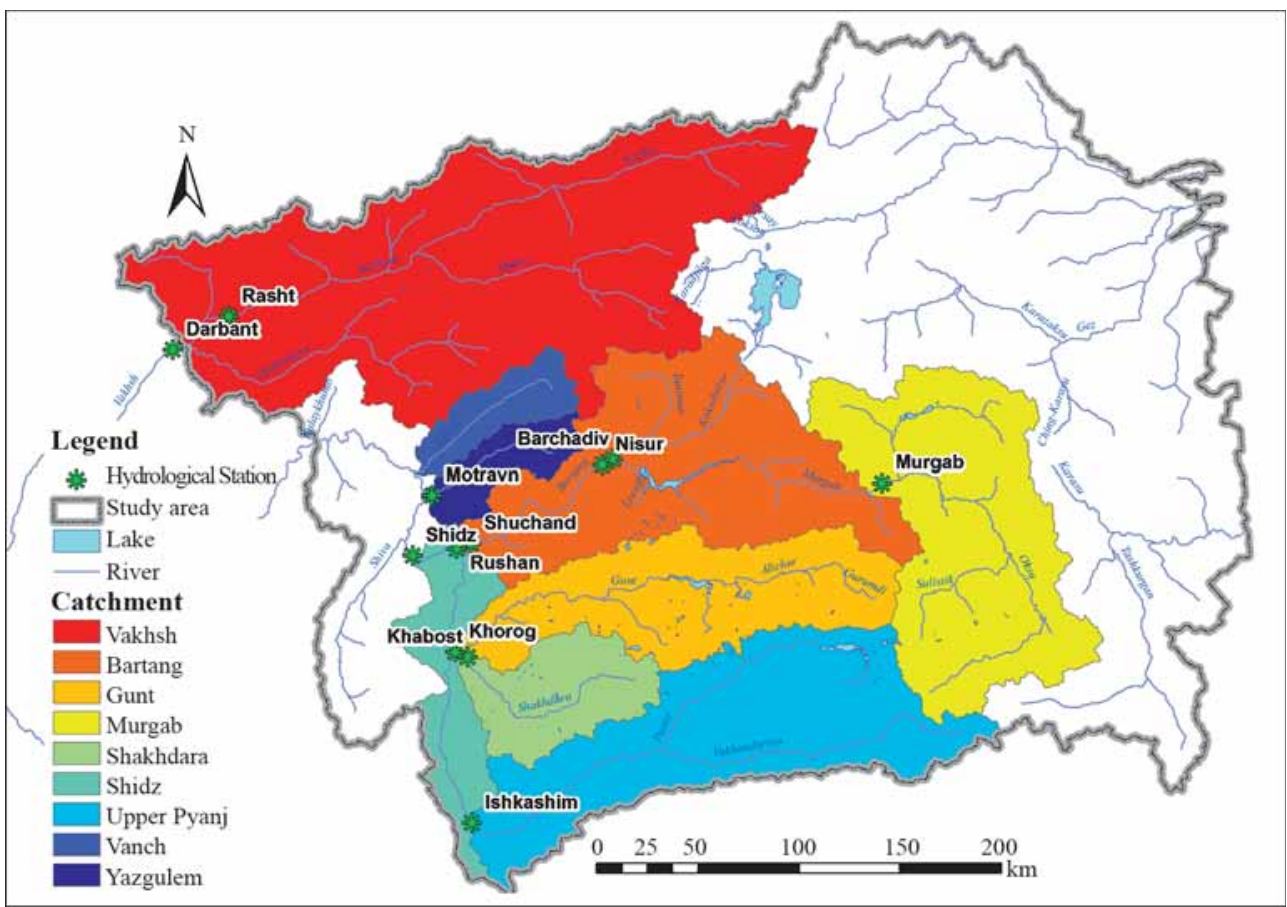

Fig. 2. Hydrological stations and river basins

part of the entire Pyanj river basin. It was impossible to obtain discharge records for the entire Pyanj river basin. Thus, assessment of runoff change in the Pamirs was done using data from two hydrological stations - Darbant and Shidz. Hydrological records from the drainless Karakul lake basin and the Tarim river basin are absent, because there are no observations in these areas.

Change of open ice area depends on climate change and can characterize glacial fluctuations. It is necessary to have long-term space images of the entire Pamirs to perform assessment. Unfortunately, such data are not available. The present study uses Landsat images covering the whole Pamir region for different time intervals. It helps to do the mosaic of debris-free ice areas. In the Pamirs, the proportion of ice covered with debris and stone fragments (moraines) is $10 \%$ on average [Schetinnikov, 1998]. Areas without debris are clearly identified and outlined on space images.

\section{RESULTS AND DISCUSSION}

Analysis of changes in climate data is based on the calculated temperature and precipitation fields.

\section{Temperature}

The analysis of temperature records from meteorological stations showed that average air temperature during the second $\mathrm{CP}$ has increased by $0.42^{\circ} \mathrm{C}$ (Table 2). It proves positive temperature trend with the rate of $1.01^{\circ} \mathrm{C} / 100$ years.

The analysis of simulated air temperature fields in the Pamirs showed that average temperature has increased by $0.44^{\circ} \mathrm{C}$ (or $1.06^{\circ} \mathrm{C} / 100$ years) in the second $\mathrm{CP}$. That value is $0.02^{\circ} \mathrm{C}$ higher than the values calculated using the observation records from the stations. Maximum warming occurred in autumn and winter seasons (up to $1^{\circ} \mathrm{C}$ ), and minimum warming was observed during summertime $\left(0.3^{\circ} \mathrm{C}\right)$. Decrease of temperature by $0.1^{\circ} \mathrm{C}$ was observed in March (Table 3 ). 
Table 2. Air temperature and precipitation from meteorological stations in the Pamirs

\begin{tabular}{|c|c|c|c|c|c|c|c|c|c|}
\hline WMO & Station & $\mathrm{H}, \mathrm{m}$ & $\begin{array}{c}\mathrm{T}_{\mathrm{ave}} \\
1927-1969\end{array}$ & $\begin{array}{c}T_{\text {ave }} \\
1970-2008\end{array}$ & $\Delta \mathrm{T}$ & $\begin{array}{c}P \\
1927-1969\end{array}$ & $\begin{array}{c}P \\
1970-2009\end{array}$ & $\begin{array}{l}\Delta \mathrm{P}, \\
\mathrm{mm}\end{array}$ & $\begin{array}{l}\Delta \mathrm{P}, \\
\%\end{array}$ \\
\hline 38840 & Komsomolabad & 1258 & 11.0 & 11.6 & 0.6 & 867 & 904 & 37 & 4.3 \\
\hline 38856 & Darvaz & 1284 & 13.9 & 14.4 & 0.5 & 508 & 473 & -36 & -7.0 \\
\hline 38851 & Rasht (Garm) & 1316 & 10.6 & 10.8 & 0.2 & 724 & 762 & 38 & 5.2 \\
\hline 38852 & Tavildara & 1616 & 8.7 & 9.0 & 0.3 & 918 & 964 & 47 & 5.1 \\
\hline 38867 & Khumrogi & 1737 & 11.9 & 12.3 & 0.4 & 200 & 201 & 1 & 0.5 \\
\hline 38951 & Rushan & 1981 & 9.5 & 9.9 & 0.4 & 245 & 273 & 28 & 11.5 \\
\hline 38744 & Lyakhsh & 1998 & 6.2 & 6.3 & 0.1 & 401 & 417 & 16 & 4.0 \\
\hline 38954 & Khorog & 2075 & 8.6 & 9.3 & 0.7 & 280 & 337 & 56 & 20.0 \\
\hline 38957 & Ishkashim & 2524 & 6.7 & 7.3 & 0.6 & 108 & 114 & 6 & 5.1 \\
\hline 38748 & Altynmazar & 2787 & 3.3 & 3.6 & 0.2 & 153 & 173 & 20 & 13.2 \\
\hline 51804 & Taxkurgan & 3090 & - & - & - & 70 & 73 & 3 & 4.7 \\
\hline 38869 & Irht & 3290 & 0.9 & 1.3 & 0.4 & 130 & 132 & 2 & 1.3 \\
\hline 38853 & Khaburabad & 3347 & -1.4 & -1.2 & 0.2 & 696 & 688 & -8 & -1.2 \\
\hline 38956 & Dzhavshangoz & 3410 & -2.1 & -1.6 & 0.5 & 139 & 137 & -2 & -1.3 \\
\hline 38878 & Murgab & 3576 & -1.6 & -1.2 & 0.3 & 80 & 70 & -10 & -13.0 \\
\hline 38953 & Bulunkul & 3744 & -5.6 & -5.6 & 0.1 & 102 & 98 & -4 & -3.9 \\
\hline 38707 & $\begin{array}{l}\text { Abramov } \\
\text { Glacier }\end{array}$ & 3840 & -4.3 & -4.0 & 0.3 & 723 & 758 & 36 & 4.9 \\
\hline 38966 & Shaimak & 3840 & -3.6 & -3.0 & 0.6 & 135 & 141 & 6 & 4.5 \\
\hline 38871 & Karakul & 3930 & -4.1 & -2.8 & 1.2 & 75 & 76 & 1 & 1.3 \\
\hline 38862 & $\begin{array}{l}\text { Fedchenko- } \\
\text { Glacier }\end{array}$ & 4169 & -7.1 & -6.7 & 0.3 & 1234 & 1285 & 51 & 4.1 \\
\hline \multicolumn{2}{|c|}{$T \& P$ year } & & 3.2 & 3.7 & 0.42 & 389 & 404 & 14 & 3.2 \\
\hline
\end{tabular}

Table 3. Air temperature for average elevation in the Pamirs ( $3760 \mathrm{~m}$ asl)

\begin{tabular}{|c|c|c|c|}
\hline Month & $\begin{array}{c}\text { Temperature } \\
\text { 1927-1969 }\end{array}$ & $\begin{array}{c}\text { Temperature } \\
\mathbf{1 9 7 0 - 2 0 0 8}\end{array}$ & $\mathbf{d T}$ \\
\hline Jan & -17.74 & -16.99 & 0.8 \\
Feb & -14.97 & -14.88 & 0.1 \\
Mar & -9.55 & -9.68 & -0.1 \\
Apr & -3.46 & -2.73 & 0.7 \\
May & 1.59 & 2.05 & 0.5 \\
June & 5.61 & 6.13 & 0.5 \\
July & 9.05 & 9.45 & 0.4 \\
Aug & 9.10 & 9.37 & 0.3 \\
Sept & 4.45 & 4.71 & 0.3 \\
Oct & -2.22 & -1.82 & 0.4 \\
Nov & -9.43 & -8.47 & 1.0 \\
Dec & -14.65 & -14.03 & 0.6 \\
Taverage & -3.52 & -3.07 & 0.44 \\
\hline
\end{tabular}

Induced by temperature growth, the elevation (asl) of the zero degree isotherm increased. The altitude of zero degree isotherm increased by $66 \mathrm{~m}$ on average in the second CP. The average elevation of the zero degree isotherm was $3220 \mathrm{~m}$ asl in the first CP, and $3286 \mathrm{~m}$ asl in the second CP. In July, the zero degree isotherm was $5090 \mathrm{~m}$ asl during the first CP, and $5168 \mathrm{~m}$ asl during the second CP. Thus, the temperature below zero is higher than this level within the whole year.

\section{Precipitation}

Atmospheric precipitation at all stations has increased by $3.2 \%$ on average during the second CP (Table 4). Analysis of simulated precipitation fields showed that the average amount of precipitation over the territory was $372 \mathrm{~mm} /$ year during the first CP, and 
Table 4. Annual precipitation in the Pamirs (water equivalent)

\begin{tabular}{|l|c|c|c|c|}
\hline \multicolumn{1}{|c|}{ Parameters } & 1927-1969 & $\mathbf{1 9 7 0 - 2 0 0 9}$ & Delta & Delta, \% \\
\hline Average precipitation, $\mathrm{mm}$ & 372 & 379 & 6 & 1.69 \\
Maximum precipitation, mm & 1337 & 1371 & 34 & 2.52 \\
Total precipitation, $\mathrm{km}^{3}$ & 58.08 & 59.05 & 0.97 & 1.67 \\
Water (liquid precipitation), $\mathrm{km}^{3}$ & 16.87 & 18.14 & 1.27 & 7.54 \\
Snow (solid precipitation), $\mathrm{km}^{3}$ & 41.21 & 40.91 & -0.30 & -0.74 \\
Water (liquid precipitation), \% & 29.0 & 30.7 & & 1.7 \\
Snow (solid precipitation), \% & 71.0 & 69.3 & & -1.7 \\
Snow accumulation volume, $\mathrm{km}^{3}$ & 14.08 & 13.62 & -0.46 & -3.28 \\
Average snow accumulation thickness, mm & 685 & 689 & 4 & 0.63 \\
Maximum snow accumulation thickness, $\mathrm{mm}$ & 1306 & 1357 & 50 & 3.85 \\
Snow accumulation volume in glacial areas, $\mathrm{km}^{3}$ & 5.81 & 5.85 & 0.05 & 0.85 \\
Precipitation volume in glacial areas, $\mathrm{km}^{3}$ & 6.72 & 6.91 & 0.20 & 2.91 \\
Precipitation volume on grounds, $\mathrm{km}^{3}$ & 51.4 & 52.1 & 0.77 & 1.51 \\
Average snow area, $\mathrm{km}^{2}$ & 97569 & 95132 & -2438 & -2.50 \\
Minimum snow area, $\mathrm{km}^{2}$ & 9291 & 6871 & -2420 & -26.05 \\
\hline
\end{tabular}

$379 \mathrm{~mm} /$ year during the second one. Volume of precipitation changed from $58.08 \mathrm{~km}^{3}$ to $59.05 \mathrm{~km}^{3}$, which illustrates increase by $1.7 \%$ in the second CP. Volume of snow over the territory decreased by $0.74 \%$. However, in the glacial area amount of snow was $2.91 \%$ higher during the second CP compared to the first one (Table 4).

Thickness of snow accumulation in water equivalent for the glacial areas varied from $49 \mathrm{~mm} /$ year to $1306 \mathrm{~mm} /$ year on average in the first CP. Maximum thickness of snow accumulation increased by $3.9 \%$ and reached $1357 \mathrm{~mm} /$ year in the second CP.

Two ice cores taken during a field study (summer 2005) in the upper reaches of the Fedchenko glacier proved that average thickness of snow accumulation in water equivalent was $1380 \mathrm{~mm} /$ year and 2080 $\mathrm{mm}$ /year, accordingly [Aisen and others 2009]. Thickness of snow accumulation for the same two ice core sites, based on our model, was $1230 \mathrm{~mm} /$ year and $1260 \mathrm{~mm} /$ year, accordingly. Thus, the difference between real measurements and calculations is $10.9 \%$ and $39.7 \%$, accordingly. There are three reasons for such variance. Firstly, different time intervals were used when comparing available data. Ice cores characterize only from 5 to 6 years period, which is obviously less than the climatic period of around 40 years determined for the present study. Secondly, snow distribution is usually uneven in mountain areas, especially aggravated by wind, frequent snowstorms, variety of land forms and other factors; however, in simulation the pixel is considered as flat surface. Thirdly, the ice core is taken from a particular point, but the model shows average precipitation over the area of one pixel $\left(0.8 \mathrm{~km}^{2}\right)$.

Maximum of precipitation occurs in the highest part of the Pamirs (up to 1371 $\mathrm{mm}$ (year), and this is the reason for big concentration of glaciers here. In the Eastern Pamirs, precipitation is less than $100 \mathrm{~mm} /$ year. Eastward moving air streams are obstructed by the Kashgar ridge located in China, and that induces up to $400-500 \mathrm{~mm}$ of precipitation per year over mountains (Fig. 3).

Balance between liquid and solid precipitation (rainfall and snow) varies within a year. In winter season, snow is observed over the 


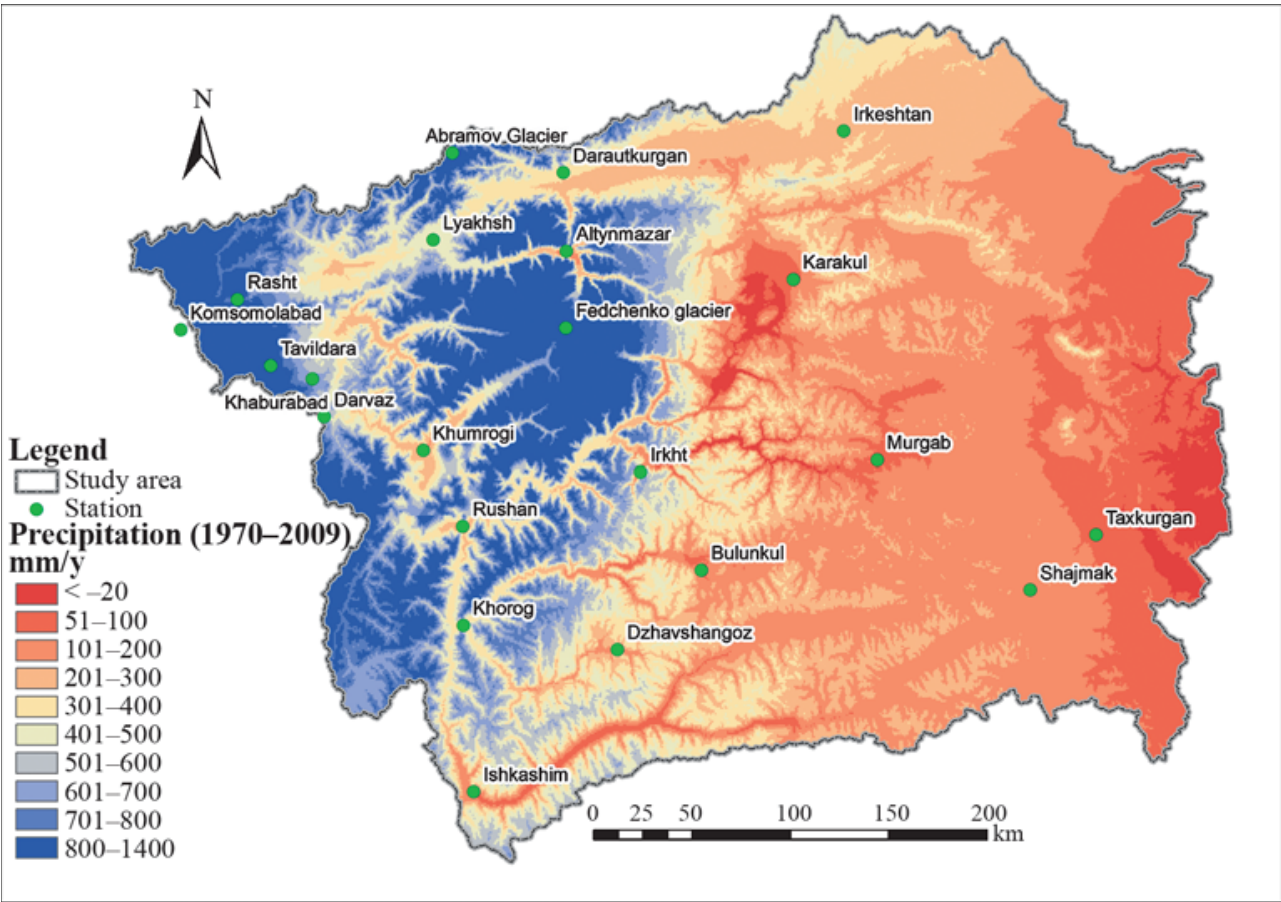

Fig. 3. Annual precipitation in the Pamirs (1970-2009)

entire Pamirs, while during summer it occurs only in high mountains. In the second CP such balance changed due to temperature growth, thus increasing rainfall and decreasing snowfall (Fig. 4).

In the first $\mathrm{CP}$, precipitation varied from 5.6 $\mathrm{mm}$ /year to $1337 \mathrm{~mm} /$ year. In the second $\mathrm{CP}$, the range of precipitation extended from $0.3 \mathrm{~mm} /$ year to $1371 \mathrm{~mm} /$ year (see Table 3). Change of precipitation throughout the study area was not similar. In the second CP, precipitation increased by $40 \mathrm{~mm} /$ year in some high mountain areas, and decreased by $20 \mathrm{~mm}$ /year over other territories (Fig. 5).

Precipitation in the glacial area in the first $\mathrm{CP}$ was $6.72 \mathrm{~km}^{3} /$ year, and in the second $C P$, it was $6.91 \mathrm{~km}^{3} /$ year showing an increase of $2.91 \%$. Precipitation over the territory without glaciers was $51.4 \mathrm{~km}^{3} /$ year during the first $C P$, and $52.1 \mathrm{~km}^{3} /$ year during the second CP (see Table 4). Maximum of snow accumulation occurred in April. In the first CP, it was $30.6 \mathrm{~km}^{3}$ / year, and in the second $C P$, it decreased by
$2.85 \%$ to $29.8 \mathrm{~km}^{3} /$ year (Fig. 6). The maximum area of snow cover occurs in January when the whole Pamir region is covered with snow.
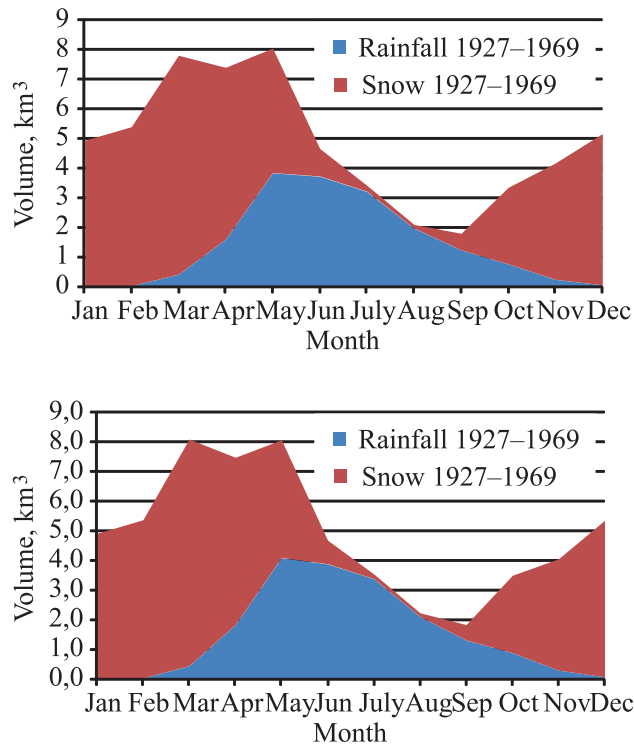

Fig. 4. Annual course of solid and liquid precipitation in the Pamir area calculated for the two periods (1927-1969 and 1970-2009) 


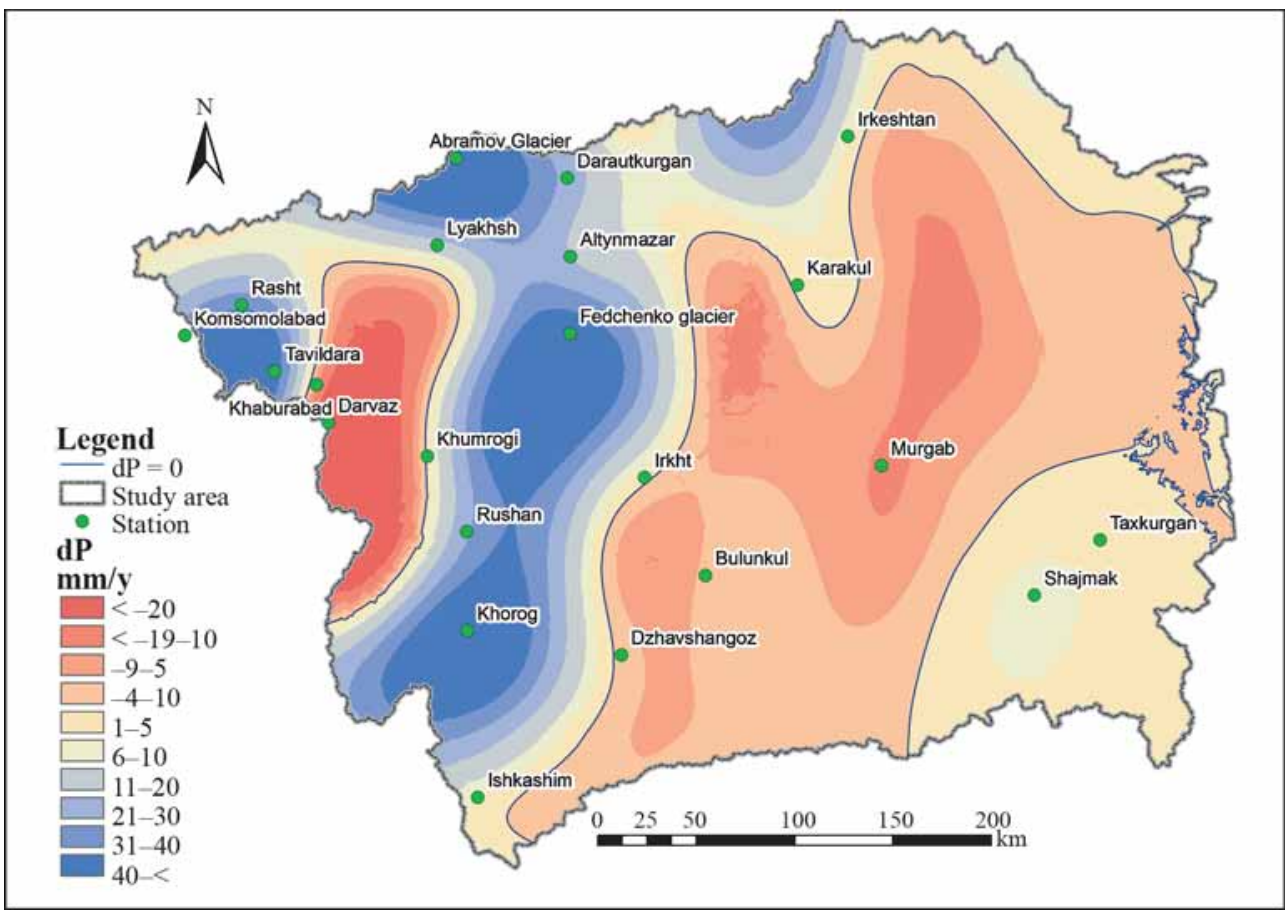

Fig. 5. Change of annual precipitation in the Pamirs during the second CP ( $\mathrm{mm} / \mathrm{year}$ )

Minimum volume of accumulated snow of less than $0.5 \mathrm{~km}^{3}\left(0.48 \mathrm{~km}^{3}\right.$ in the first CP and $0.46 \mathrm{~km}^{3}$ in the second (P) is observed in August, and the minimum area of snow cover is observed in July $\left(9291 \mathrm{~km}^{2}\right.$ in the first (P and $6871 \mathrm{~km}^{2}$ in the (P). In July snow cover volume decreased by $21 \%$ due to area reduction (Fig. 6). The minimum area of snow accumulation in the same month decreased by $26.05 \%$ during the second CP. The maximum thickness of snow cover increased by $3.85 \%$. However, the average annual snow accumulation volume decreased by $3.28 \%$ in the second CP (see Table 4).

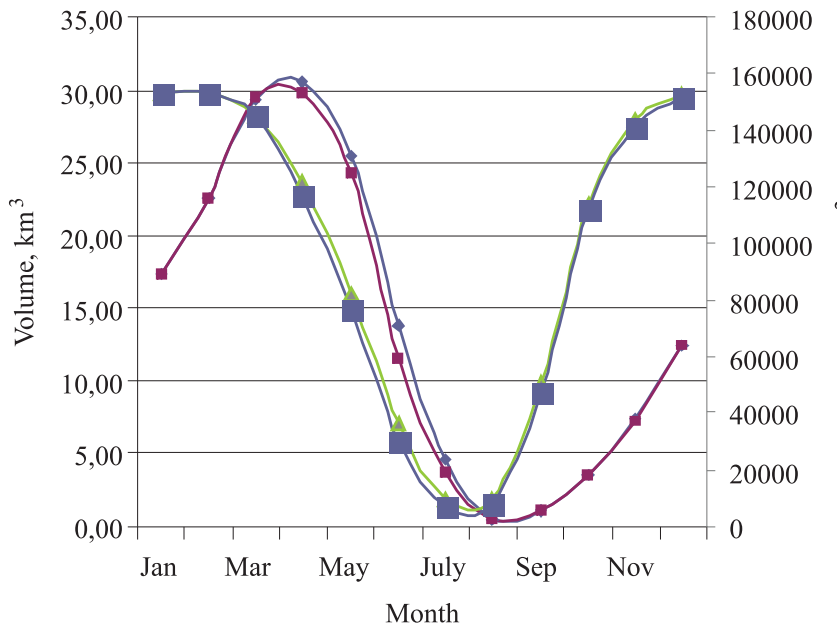

$\longrightarrow$ Accumulation volume, 1927-1969

$\rightarrow$ Accumulation volume, 1970-2009

-Area 1927-1969

Area 1970-2009

Fig. 6. Change of the snow cover area and water volume in snow on the Pamirs 
For a better understanding of climate change, calculation of the seasonal precipitation changes for the three decades from 1981 to 2010 has been made.

Analysis of precipitation change over decades showed the following picture. During the period of 1981-1990, amount of precipitation was $55.9 \mathrm{~km}^{3} /$ year. In the next period of $1991-$ 2000 , precipitation increased up to $59.8 \mathrm{~km}^{3}$ / year. In the period of 2001-2010, precipitation decreased again to $57.7 \mathrm{~km}^{3} /$ year. In winter season continuous increase of precipitation was observed. During spring and summer seasons precipitation increase occurred in the second decade (1991-2000) (Fig. 7).

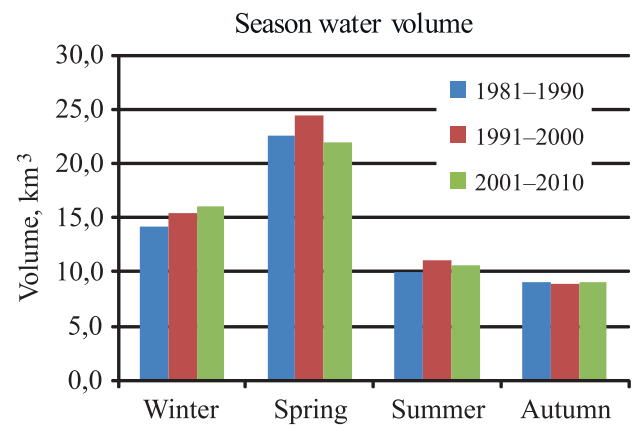

Fig. 7. Seasonal change of precipitation over decades

\section{Glacial zone}

The area of open ice calculated based on Landsat images was $10382 \mathrm{~km}^{2}$ or $7 \%$ of the total area of the entire Pamirs (Table 5). The greatest glacial areas can be found in the Pyanj river basin $\left(3702.82 \mathrm{~km}^{2}\right)$; however, the share of glaciers in the total basin is only $5.2 \%$. The biggest share of glacial areas can be found in the Vakhsh river basin, which is $12.2 \%$ of the total catchment. Mean annual snow cover area across the Pamirs decreased by $2.5 \%$ during the second CP. Maximum reduction of mean annual snow cover area by $2.7 \%$ occurred in the Vakhsh river basin.

\section{Distribution of precipitation throughout river basins}

Assessment of precipitation distribution throughout river basins showed increase from $1.3 \%$ (the Vakhsh river) to $2.4 \%$ (the Pyanj river) in western part of the Pamirs during the second CP (1970-2009). In the Karakul lake basin precipitation increased by $4.1 \%$, and in Chinese part of the Pamir it decreased by $0.9 \%$ (Table 6). Precipitation increased by $1.7 \%$ or $0.97 \mathrm{~km}^{3} /$ year across the entire Pamirs in the second $C P$.

The Tarim river basin. During the first CP precipitation varied from $30 \mathrm{~mm} /$ year to $609 \mathrm{~mm} /$ year in the Tarim river basin near the Kashgar ridge, and the average value was $164.9 \mathrm{~mm} /$ year. During the second CP precipitation varied from $30 \mathrm{~mm} /$ year to 613 $\mathrm{mm} /$ year, and the average value was 163.5 $\mathrm{mm} /$ year (Table 7). Thus, a small reduction of precipitation volume (-0.9\%) with increased range was observed.

Despite decrease of snow cover area in the Tarim river basin by $4.9 \%$ during the second $\mathrm{CP}$, snow volume in glacial zone of the Kashgar ridge increased by $1.8 \%$ (see Table 6).

Table 5. Distribution of glacial areas in river basins of the Pamirs

\begin{tabular}{|c|c|c|c|c|c|c|}
\hline \multirow{2}{*}{ Basin } & \multicolumn{3}{|c|}{ River basins \& glaciation areas } & \multicolumn{3}{|c|}{ Average snow area, $\mathrm{km}^{2} /$ year } \\
\hline & Basin area, km² $^{2}$ & Glacial area, km² & Glacial area, $\%$ & 1927-1969 & 1970-2009 & Delta, \% \\
\hline Tarim & 44157 & 2743.42 & 6.2 & 27481 & 26754 & -2.6 \\
\hline Karakul & 4549 & 407.19 & 9.0 & 3488 & 3411 & -2.2 \\
\hline Pyanj & 71648 & 3702.82 & 5.2 & 49673 & 48506 & -2.3 \\
\hline Vakhsh & 28964 & 3528.89 & 12.2 & 16890 & 16425 & -2.7 \\
\hline Total & 149318 & 10382.32 & 7.0 & 97532 & 95096 & -2.5 \\
\hline
\end{tabular}


Table 6. Average annual precipitation in river basins (water equivalent)

\begin{tabular}{|c|c|c|c|c|c|c|c|c|c|}
\hline \multirow{2}{*}{ Basin } & \multicolumn{3}{|c|}{ Precipitation, $\mathrm{km}^{3} / \mathrm{year}$} & \multicolumn{3}{|c|}{ Snow, $\mathrm{km}^{3} /$ year } & \multicolumn{3}{|c|}{$\begin{array}{c}\text { Snow in glacial areas, } \\
\mathrm{km}^{3} / \text { year }\end{array}$} \\
\hline & $\begin{array}{c}1927- \\
1969\end{array}$ & $\begin{array}{c}1970- \\
2009\end{array}$ & $\begin{array}{c}\text { Change, } \\
\%\end{array}$ & $\begin{array}{c}1927- \\
1969\end{array}$ & $\begin{array}{c}1970- \\
2009\end{array}$ & $\begin{array}{c}\text { Change, } \\
\%\end{array}$ & $\begin{array}{c}1927- \\
1969\end{array}$ & $\begin{array}{c}1970- \\
2009\end{array}$ & $\begin{array}{c}\text { Change, } \\
\%\end{array}$ \\
\hline Tarim & 7.28 & 7.22 & -0.9 & 3.56 & 3.39 & -4.9 & 0.61 & 0.63 & 1.8 \\
\hline Karakul & 0.91 & 0.95 & 4.1 & 0.74 & 0.75 & 2.3 & 0.20 & 0.21 & 4.0 \\
\hline Pyanj & 30.85 & 31.59 & 2.4 & 24.00 & 24.09 & 0.3 & 2.76 & 2.87 & 3.9 \\
\hline Vakhsh & 19.05 & 19.30 & 1.3 & 12.91 & 12.68 & -1.8 & 3.14 & 3.21 & 2.2 \\
\hline Total & 58.08 & 59.05 & 1.7 & 41.21 & 40.91 & -0.7 & 6.72 & 6.91 & 2.9 \\
\hline
\end{tabular}

Table 7. Average annual precipitation in river basins of the Pamirs

\begin{tabular}{|l|c|c|c|c|}
\hline \multirow{2}{*}{ Basin } & \multicolumn{2}{|c|}{ Precipitation, $\mathrm{mm} / \mathrm{y}$} & \multirow{2}{*}{$\mathrm{dP}, \mathrm{mm} / \mathrm{y}$} & $\mathrm{dP} \%$ \\
\cline { 2 - 3 } & $1927-1969$ & $1970-2009$ & & $-0.9 \%$ \\
\hline Tarim & 164.93 & 163.48 & -1.45 & $4.1 \%$ \\
Karakul & 199.79 & 207.96 & 8.17 & $2.4 \%$ \\
Pyanj & 430.52 & 440.86 & 10.35 & $1.3 \%$ \\
Vakhsh & 657.57 & 666.35 & 8.78 & $1.7 \%$ \\
Total & 388.99 & 395.48 & 6.49 & \\
\hline
\end{tabular}

The share of average annual precipitation in the Tarim river basin relative to the entire Pamirs was $12.5 \%$ during the first $C P$, and $12.2 \%$ during the second one. The share of snow in the glacial areas did not change and was $1.06 \%$ (Table 8 ).

The Karakul lake basin. Annual precipitation in the Karakul lake basin increased by $4.1 \%$ during the second $C P$, i.e. from $199,8 \mathrm{~mm} /$ year to $208 \mathrm{~mm} /$ year, or from $0.91 \mathrm{~km}^{3} /$ year to $0.95 \mathrm{~km}^{3} /$ year (see Table 6,
Table 7). Quantity of snow throughout the entire basin increased by $2.3 \%$; amount of snow in glacial areas increased by $4 \%$. The share of annual precipitation in the Karakul lake basin relative to the entire Pamirs remained constant at $1.6 \%$. The share of snow in the total precipitation was $1.3 \%$, and the share of snow in the glacial area was $0.35 \%$.

The Pyanj river basin. Average precipitation in the Pyanj river basin was $430.5 \mathrm{~mm}$ /year during the first CP and $440.9 \mathrm{~mm} /$ year

Table 8. Share of basin total precipitation, solid precipitation (snow) and solid precipitation in glaciated areas in total precipitation over the Pamirs

\begin{tabular}{|l|c|c|c|c|c|c|}
\hline \multirow{2}{*}{ Basin } & \multicolumn{2}{|c|}{ Precipitation, \% } & \multicolumn{2}{c|}{ Snow, \% } & \multicolumn{2}{c|}{ Snow in glacial areas, \% } \\
\cline { 2 - 7 } & $\mathbf{1 9 2 7 - 1 9 6 9}$ & $\mathbf{1 9 7 0 - 2 0 0 9}$ & $\mathbf{1 9 2 7 - 1 9 6 9}$ & $\mathbf{1 9 7 0 - 2 0 0 9}$ & $\mathbf{1 9 2 7 - 1 9 6 9}$ & $\mathbf{1 9 7 0 - 2 0 0 9}$ \\
\hline Tarim & 12.5 & 12.2 & 6.1 & 5.7 & 1.06 & 1.06 \\
Karakul & 1.6 & 1.6 & 1.3 & 1.3 & 0.35 & 0.35 \\
Pyanj & 53.1 & 53.5 & 41.3 & 40.8 & 4.75 & 4.85 \\
Vakhsh & 32.8 & 32.7 & 22.2 & 21.5 & 5.41 & 5.44 \\
Total & 100.0 & 100.0 & 71.0 & 69.3 & 11.57 & 11.71 \\
\hline
\end{tabular}


during the second one (see Table 7), i.e., $30.85 \mathrm{~km}^{3} /$ year and $31.59 \mathrm{~km}^{3} /$ year, accordingly (see Table 6). Amount of snow increased by $0.3 \%$ reaching $24.09 \mathrm{~km}^{3} /$ year during the second CP. In the glacial area, snow volume increased by $3.9 \%$ reaching $2.87 \mathrm{~km}^{3}$ /year during the second CP. The share of precipitation in the Pyanj river basin in the total area was $53.1 \%$ in the first CP, and $53.5 \%$ in the second one (Table 8). The share of snow in the total precipitation decreased from $41.3 \%$ to $40.8 \%$, and in the glacial areas it increased from $4.75 \%$ to $4.85 \%$ during the second CP.

The Vakhsh river basin. The most intensive precipitation was observed in the Vakhsh river basin - from $657.57 \mathrm{~mm} /$ year in the first CP to $666.35 \mathrm{~mm} /$ year in the second one (see Table 7). Volume of precipitation increased from $19.05 \mathrm{~km}^{3}$ /year during the first CP to $19.30 \mathrm{~km}^{3}$ / year during the second one (see Table 6). The average annual amount of snow throughout the basin decreased by $1.8 \%$ in the second CP. During the first $C P$, the amount of snow was $12.9 \mathrm{~km}^{3} /$ year, and during the second one it was $12.7 \mathrm{~km}^{3} /$ year. In the glacial area, snow was $3.14 \mathrm{~km}^{3} /$ year during the first CP and $3.21 \mathrm{~km}^{3} /$ year during the second one, which is $2.2 \%$ greater. The share of precipitation relative to the total amount for the entire Pamirs was $32.8 \%$ in the first CP and $32.7 \%$ in the second one; the amount of snow was $22.2 \%$ and $21.5 \%$ respectively. The share of snow in the glacial area of the Vakhsh river basin relative to the total precipitation for the entire Pamirs was $5.41 \%$ in the first CP and $5.44 \%$ in the second one.

The share of snow in the first CP throughout the entire Pamirs was $71 \%$ (Table 8); in the second one it was $1.7 \%$ smaller. However, in the glacial area, the amount of snow was $0.14 \%$ greater during the second CP compared to the first one.

\section{River discharge}

As it was mentioned above, the Vakhsh river basin discharge is characterized by records obtained from the Darbant station. The area of the Vakhsh river basin upstream from this station is $29005 \mathrm{~km}^{2}$. The area of the Pyanj river basin, upstream of the Shidz station, is $60044 \mathrm{~km}^{2}$. Historical data show a slight tendency for water discharge decrease during the entire observation period. However, increase of water discharge in the Vakhsh river can be noticed since 1974 (Fig. 8).

In the second CP precipitation increased by $2,8 \%$ in the Vakhsh river basin, and by 1,7\% in the Pyanj river basin. However, river discharge in the second CP decreased by 5,1\% in the

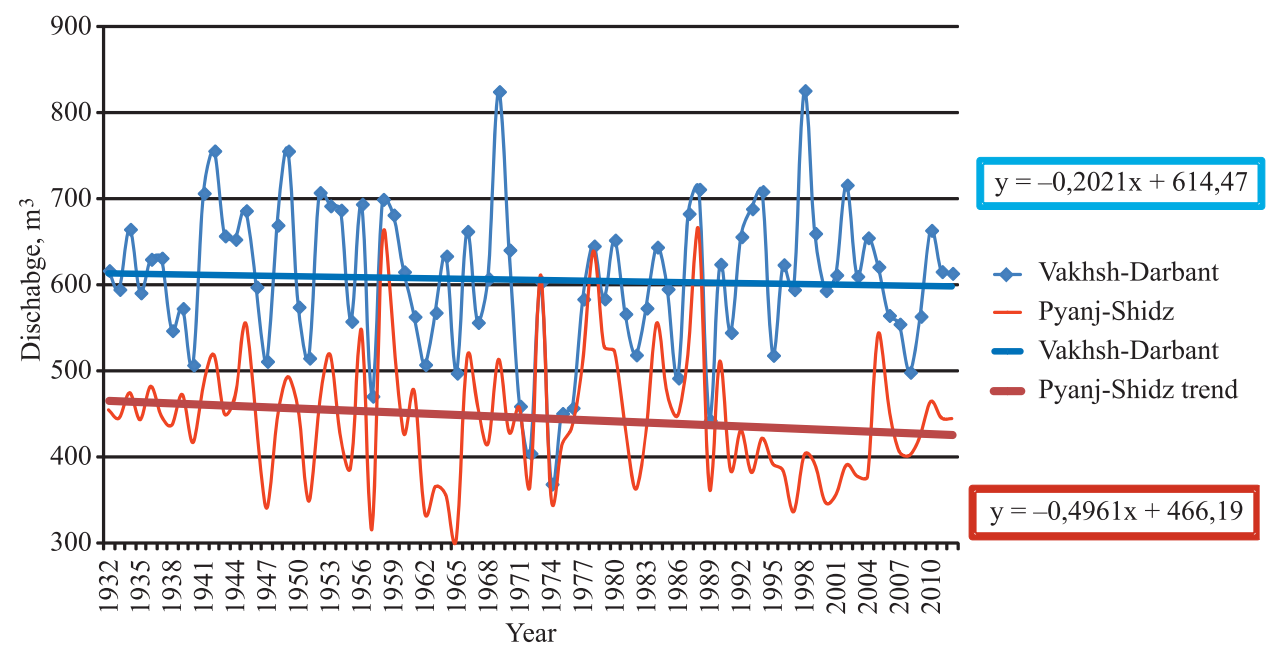

Fig. 8. Water discharge in the Vakhsh-Darbant and Pyanj-Shidz rivers 
Vakhsh river basin, and by 1,8\% in the Pyanj river basin (Fig. 9).
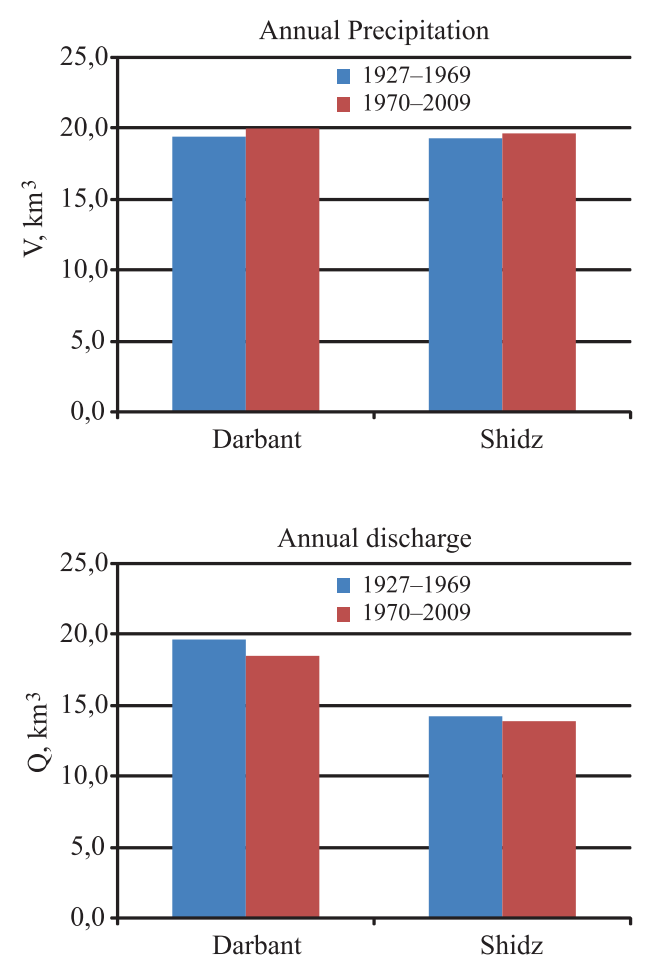

Fig. 9. Change of precipitation and water discharge in the Vakhsh (Darbant) and Pyanj (Shidz) basins.

Reduction of water discharges while precipitation grows can be explained by two factors. Firstly, rise of temperature increases evaporation. Secondly, in high mountains precipitation grows without thawing, which results in snow accumulation increase.

\section{Circulation Index and climate fluctuation in the Pamirs}

The Pamir Mountains lie between 36 and 39 degree of the northern latitude. The Polar front zone is supposed to be at the same latitude which separates tropical and moderate air masses. Displacement of this front northwards or southwards affects weather over the Pamirs. Apart from seasonal shifts, front disposition is influenced by a long-term change of cyclones and anticyclones related to polar fronts. It results in change of atmospheric circulation with subsequent long-term variations of temperature and precipitation cycles in the Pamirs. When such variations last over several decades, they can be considered as climatic periods.

In the middle of the $X X^{\text {th }}$ century Prof. B.L. Dzerdzeevsky and his colleagues published number of studies about global circulation features in the Northern hemisphere (Dzerdzeevsky and others, 1946; Dzerdzeevsky, 1975). Later the same scientists developed Classification of atmospheric circulation features in the Northern hemisphere, which became useful for identifying of 41 Elementary Circulation Patterns (ECP). The researchers proved that during a long-time interval (of several years) there are certain types of circulation which influence cyclones or anticyclones shifting latitudinally or longitudinally. Thus, variable air stream routes can significantly impact on climate change in particular regions.

In the present study, the authors have tested the mentioned Classification of circulation patterns and periods in the Northern hemisphere (http://atmospheric-circulation. ru) for climate change assessment in the Pamir region. Thus, the total circulation index for decadal moving average has been used together with mean annual precipitation in the Pamirs for the same decades (Fig. 10). Approximation by a polynomial of the sixth order showed nearly synchronically change of precipitation and circulation. Such correlation illustrates impact of global circulation processes on climate change in the Pamirs. It reflects the influence of global circulation processes on climate of the Pamirs

\section{CONCLUSION}

The present work allowed estimating climate change and its impact on water resources of the Pamir region during the observation period (1927-2009). The findings revealed average increase of air temperature and precipitation in the second half of the whole chronological 


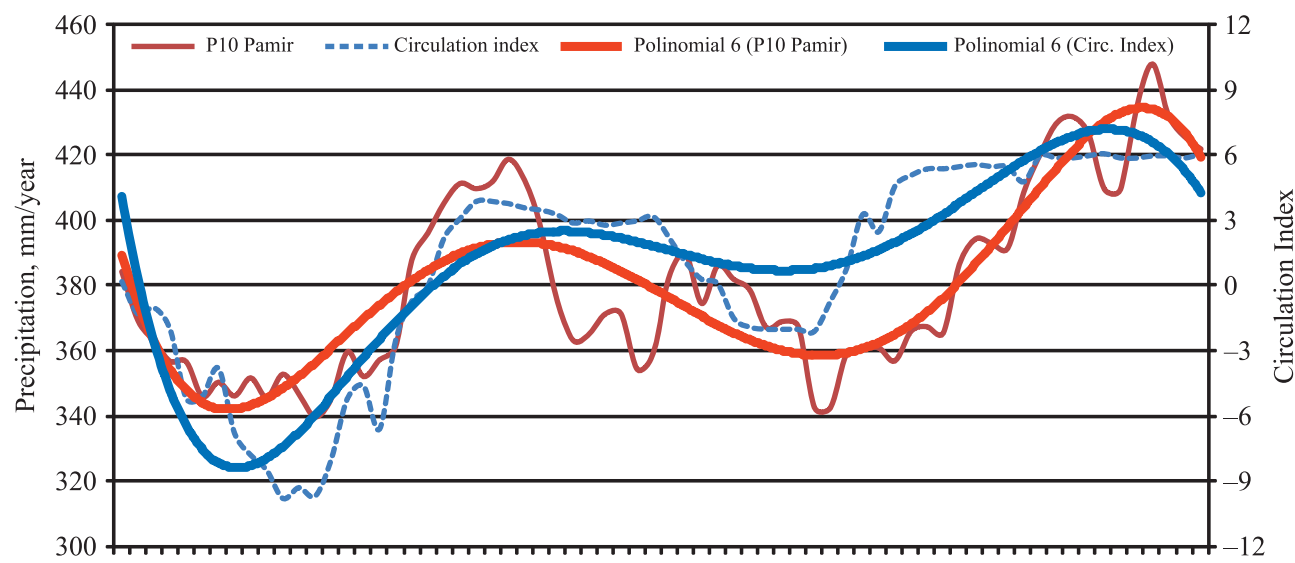

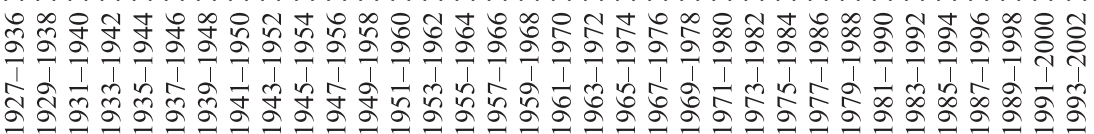

Decade

Fig. 10. Total circulation index and average annual precipitation in the Pamirs

Legend: P10 Pamir - total annual precipitation in the Pamirs per 10 years; Circulation Index $=Z+V z+M n+M s$ ( $Z$ - zonal circulation index; Vz - zonal circulation disturbance index; $M n$ - northern meridional circulation index; Ms - southern meridional circulation index).

interval. In the western and northern areas of the Pamirs precipitation increased, while in the eastern part a small decrease was observed. Snow accumulation increased by $2.9 \%$ in the upper reaches of glaciers. Despite this, winter snow stocks decreased due to reduction of the entire snow area by $2.5 \%$. It can be assumed that in the next period glaciers located below $3200 \mathrm{~m}$ as I will continue to shrink until they gain mass balance. Thawing of glaciers will slightly increase at the elevation between $3200 \mathrm{~m}$ and $5100 \mathrm{~m}$ asl. At the same time, snow will be accumulated in the areas higher than $5100 \mathrm{~m}$ asl. When getting a critical mass, it is likely for glaciers to start shifting downwards. Thus, the glacial area at high altitudes can be extended. Hydrological characteristics in rivers of the Pamirs varied within several percent. Therefore, no trends of discharge change were revealed in the upper parts of the Pyanj and Vakhsh river basins.
Climate change in the Pamirs can, probably, be related to global circulation processes in the atmosphere. This point of view is supported by good correlation between the atmospheric circulation index and long-term variations in precipitation.

\section{ACKNOWLEDGEMENTS}

The authors express their gratitude to the State Key Laboratory of Cryospheric Sciences, Cold and Arid Regions Environmental and Engineering Research Institute of the Chinese Academy of Sciences for providing good environment and all possible assistance in the abovementioned joint research. This study was partially supported by the Ministry of Science and Technology (grant № 2010DFA9272023), the Chinese Academy of Science (KZZDEW-12-1) and the Natural Science Foundation of China (41130641).

\section{REFERENCES}

1. Aizen V., Mayewski P., Aizen E, Joswiak D, Surazakov A, Kaspari S, Grigholm B, Krachler M, Handley M, Finaev A. (2009). Stable-isotope and trace element time series from Fedchenko glacier (Pamir) snow/firn cores. Journal of Glaciology, Vol. 55, No. 190, 2009, pp. 275-291. 
2. Katalog lednikov SSSR. [USSR Glacier Inventory]. (1968). Tom 14. Srednjaja Azija. Vypusk 3. Chasti 4-18. Gidrometeoizdat. Leningrad. 64 p. (in Russian).

3. Catalogue of Pamir and Hissar-Alay glaciation for 1980 (database of A.S. Schetinnikov). (2011). Ed: M. Glazirina. UNDP. 564 p.

4. Climate Resiliency for Natural Resources Investments. (2011) Asian Development Bank. Project TA 7599-TAJ. 158 p.

5. Drozdov O.A., Vasil'ev V.A., Kobysheva N.V., Raevskij A.N., Smekalova L.K., Shkol'nyj E.P. (1989) Klimatologija [Climatology]. Leningrad. Gidrometeoizdat. 568 p. (in Russian).

6. Dzerdzeevskij B.L. (1975). Obshhaja cirkuljacija atmosfery i klimat [General atmospheric circulation and climate]. Izbrannye trudy. M. Nauka. 287 p. (in Russian)

7. Dzerdzeevskij B.L., Kurganskaja Z.M., Vitvitskaja Z.M. (1946) Tipizacija cirkuljacionnykh mehanizmov v Severnom polusharii i kharakteristika sinopticheskikh sezonov. [Classification of atmospheric circulation features in the Northen hemisphere including typifying of synoptic seasons]. Trudy NIU GUGMS. Gidrometeoizdat. 80 p. (in Russian).

8. Finaev A.F. (1999) Climatic Changes in the Mountain Glacier Area of Pamir. In NATO ASI Series I, Vol. 56. Ice Physics in the Natural Environment. (Eds. Wettlaufer/Dash/Untersteiner). Springer-Verlag. Berlin, Heidelberg, pp. 289-294.

9. Finaev A.F. (2013) Dinamika oledenenija nekotorykh rajonov Pamir-Alaja [Glaciation dynamics in some areas of the Pamir and Pamir-Alay]. Voprosy geografii i geojekologii. TOO "Institut geografii". Almaty. № 3. pp. 32-42. (in Russian).

10. Oledenenie Pamiro-Alaja [Glacial areas of the Pamir-Alay]. (1993). Editor V.M. Kotlyakov M., "Nauka”. 256 p. (in Russian).

11. Glazyrin G.E. (1991). Gornye lednikovye sistemy, in struktura i jevoljucija [Glacial mountain systems, their structure and evolution]. L., GIMIZ. 109 p. (in Russian).

12. Glazyrin G.E., Finaev A.F. (2003). Prognoz izmenenija oledenenija gor Zapadnogo Tadzhikistana [The forecast of mountain glaciation change in Western Tajikistan]. MGl Moskva. 2003. Vypusk 95, pp. 102-106. (in Russian).

13. Hijmans R.J., Cameron S.E., Parra J.L., Jones P.G. and Jarvis A. (2005) Very high resolution interpolated climate surfaces for global land areas. International Journal of Climatology 25: 1965-1978 (2005), pp. 1965. http://www.worldclim.org/worldclim_IJC.pdf

14. Liu Shiyin, Ding Yongjian. (2008) Glacier changes in West China. In Book: Concise glacier inventory of China.Editor: Shi Yafeng. Shanghai Popular Science Press, pp. 174-181.

15. Narovljanskij G.Ja. (1968) Aviacionnaja klimatologija [Aviation climatology]. L. Gidrometeoizdat. 268 p. (in Russian).

16. Pedhazur Elazar J. (1982) Multiple regression in behavioral research: Explanation and prediction (2nd ed.). New York: Holt, Rinehart and Winston. ISBN 0-03-041760-0. 
17. Shhetinnikov A.S. (1998) Morfologija i rezhim lednikov Pamiro-Alaja [Morphology and mode of glaciers in the Pamir-Alay]. Red. G.E. Glazyrin. SANIGMI. Tashkent. 220 p. (in Russian).

18. Tandong Yao, Thompson L., Wei Yang, Wusheng Yu, Yang Gao, Xuejun Guo, Xiaoxin Yang, Keqin Duan, Huabiao Zhao, Baiqing Xu, Jiancheng Pu, Anxin Lu, Yang Xiang, Dambaru B. Kattel and Daniel Joswiak. (2012) Different glacier status with atmospheric circulations in Tibetan Plateau and surroundings. Nature Climate Change Letters. Published online 15 july 2012. Macmillan Publishers Limited.

19. The international meteorological dictionary. WMO, (1992).

20. Unger-Shayesteh K., Vorogushyn S., Farinotti D., Gafurov A., Duethmann D., Mandychev A. and Merz B. (2013) What do we know about past changes in the water cycle of Central Asian headwaters? A review. Global and Planetary Change, 110: 4-25.

Received 03.03.2016

Accepted 29.08.2016

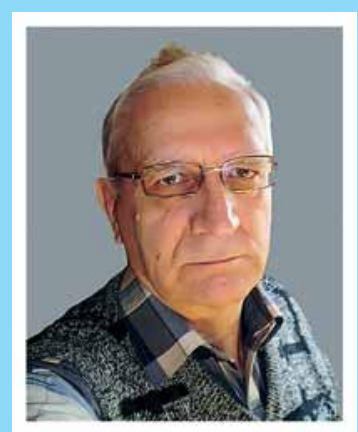

Alexander F. Finaev obtained the Ph. D. in Geography in 1988 from the Leningrad Hydrometeorological Institute (LHMI), which he had graduated earlier as an engineer-meteorologist. At present, he is the Head of Laboratory for Climatology and Glaciology of the Institute of Water Issues, Hydropower and Ecology, Academy of Sciences of the Republic of Tajikistan. The current scientific interests are in the field of climate change and its impact on the environment. He studied the radiation balance, aerosol pollution, bio climate, climate and glaciation change, hydrometeorological observations and assessment of the synoptic processes in Tajikistan. He published more than 60 papers.

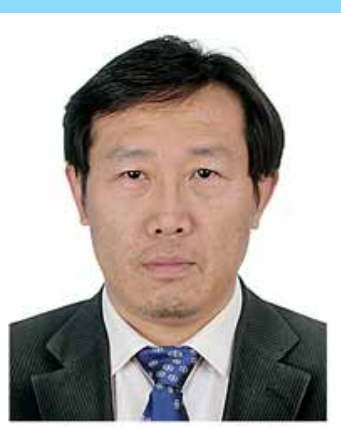

Shiyin Liu is Professor of the Cold and Arid Regions Environmental and Engineering Research Institute, the Chinese Academy of Sciences (CAREERI, CAS). He graduated from the Lanzhou University and received his master and Ph. D. degrees in 1989 and 1996 at the Lanzhou Institute of Glaciology and Geocryology, CAS. He studied mass balance modeling of glaciers and is now working in remote sensing of glaciers, glacier hazards and glacier hydrology. He has led projects for the new glacier inventory of China and the monitoring of mass changes of glaciers in China. He has authored and coauthored over 100 papers in international journals and some book chapters. He is an editorial board member of some English and Chinese journals. 

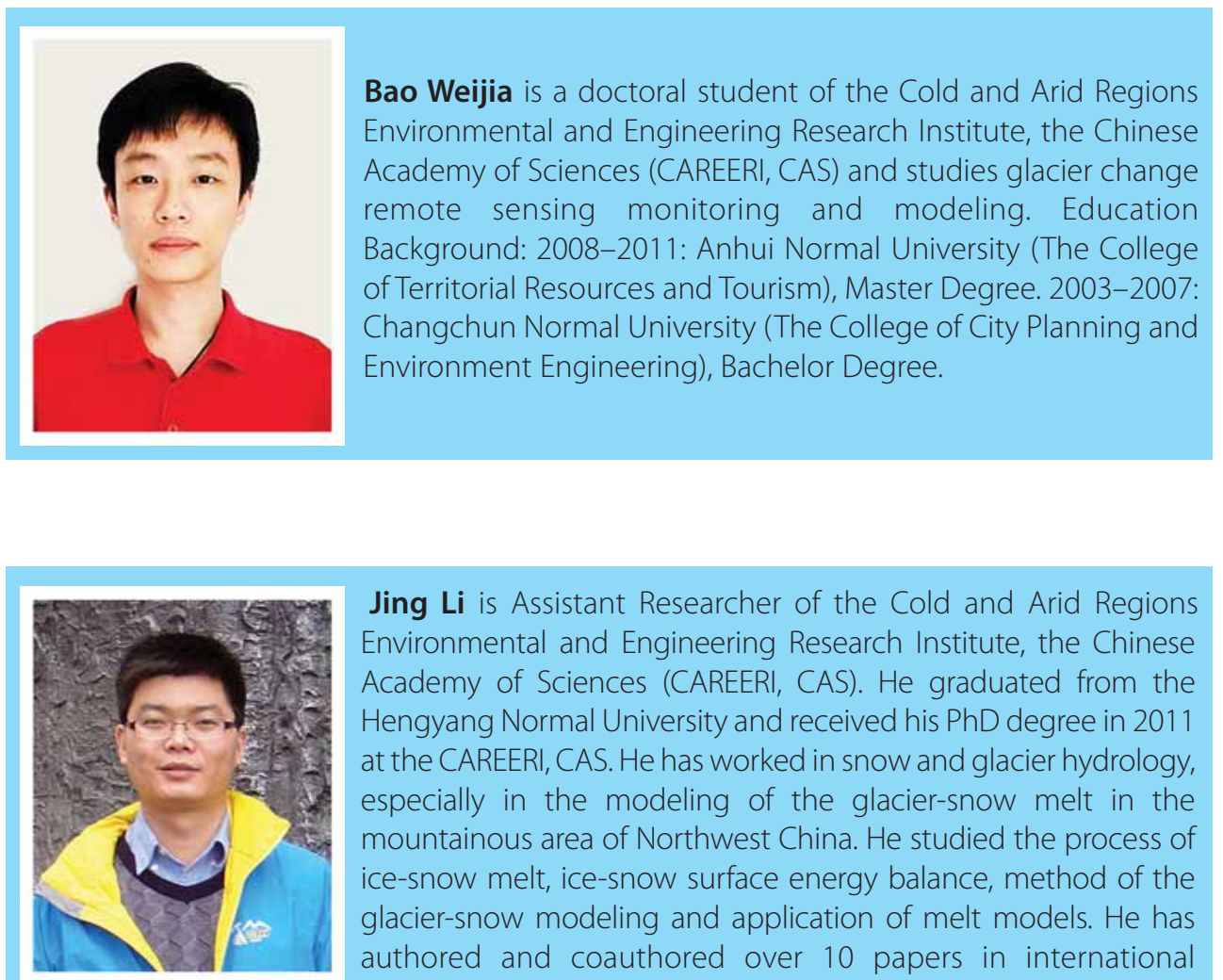

Jing Li is Assistant Researcher of the Cold and Arid Regions Environmental and Engineering Research Institute, the Chinese Academy of Sciences (CAREERI, CAS). He graduated from the Hengyang Normal University and received his PhD degree in 2011 at the CAREERI, CAS. He has worked in snow and glacier hydrology, especially in the modeling of the glacier-snow melt in the mountainous area of Northwest China. He studied the process of ice-snow melt, ice-snow surface energy balance, method of the glacier-snow modeling and application of melt models. He has authored and coauthored over 10 papers in international journals. He has also been invited as reviewer for several journals 